\title{
Inter-relationship among Economic Growth, Savings and Inflation in Pakistan
}

\author{
Muhammad Ilyas $^{1, *}$, Hazoor Muhammad Sabir ${ }^{2}$, Anam Shehzadi ${ }^{3}$, Naeem shoukat ${ }^{4}$ \\ ${ }^{1}$ M.Phil Scholar of Economics, G.C University, Faisalabad, Pakistan \\ ${ }^{2}$ Associate Professor, Department of Economics, G.C University, Faisalabad, Pakistan \\ ${ }^{3}$ Lecturer, Department of Economics, G.C University, Faisalabad, Pakistan \\ ${ }^{4}$ Student of BS Economics, G.C University Faisalabad, Pakistan \\ *Corresponding author: Ilyas_m.phileconomics@hotmail.com
}

Received February 27, 2014; Revised February 28, 2014; Accepted April 03, 2014

\begin{abstract}
The main purpose of this study was to investigate the inter-relationship among economic growth, savings and inflation and to estimate the threshold level of inflation for the economy of Pakistan. Annually time series data from 1973 to 2010 were used. Simultaneous equation model was used in the study. Three equations were used. 2SLS technique was applied for findings the results. OLS model was used for investigating the suitable rate of inflation for the economic growth. Inflation, economic growth and savings were endogenous variables while unemployment, foreign direct investment, depreciation rate, real interest rate, total debt servicing, indirect taxes, dependency ratio and total investment were exogenous variables. The results of 2SLS showed that inflation and real interest rate negatively and significantly affect the economic growth, whereas depreciation rate positively affect the economic growth. Economic growth, unemployment and real interest rate were negatively affecting the inflation rate, while indirect taxes had positive impact on inflation. The results also showed that economic growth, dependency ratio (\% of working age population) and foreign direct investment were beneficial for enhancing the savings of a country, while depreciation rate is harmful for savings. It was also observed that there is no significant relationship between inflation and savings. The findings of OLS indicated that $9 \%$ rate of inflation was to leralable for the economic growth of Pakistan.
\end{abstract}

Keywords: economic growth, inflation, savings, threshold level of inflation, 2SLS

Cite This Article: Muhammad Ilyas, Hazoor Muhammad Sabir, Anam Shehzadi, and Naeem shoukat, "Interrelationship among Economic Growth, Savings and Inflation in Pakistan.” Journal of Finance and Economics, vol. 2, no. 4 (2014): 125-130. doi: 10.12691/jfe-2-4-4.

\section{Introduction}

The basic purpose of this study is to observe the interrelationship among Economic growth, savings and inflation in Pakistan. Inflation is a multipart economic experience that has still broad attention of the macroeconomists, policymakers and the central bankers from all over the world. It is also a major issue of the macro-economic and one of the main principal concerns of the policy-makers and the public. Inflation has turned into one of the most essential topic for research for the duration of the last various decades because it plays a very important function for the determinant of economic growth and the income distribution. The basic objective of the macroeconomics policymakers is to get high and sustained economic growth with low inflation [1].

In Pakistan inflation is raising rapidly. Much of the inflation in Pakistan is cause by increase in food prices. It might be due to less productivity of agriculture sector or could be the result of so called shortage of goods and services in the economy developed by manufacturing sector giants. Rising import prices is also considered one important factor affecting the inflation. Depreciating exchange rate in this scenario can also put upward pressure growth or economy [3].

Growth experience in south-east and south Asia has generated keen interest among economists and policy makers for the last two decades. Numerous macroeconomic factors affecting economic growth like inflation, savings, foreign exchange rate, etc. have widely varying values across these nations and so also their economic growth. However, almost all these nations are growing at relatively fast rate. Since the growth in some of these economies is often considered resource intensive rather than technology intensive (Rosegrant and Evenson [29]; The World Bank [32]).

Pakistan experienced an even growth pattern since its self-government. On the average GDP growth rate of Pakistan was remained at 4 percent. This economy also practiced high inflation rate and unemployment during the most period of time since its inception [21]. GDP is an important indicator for the economy of a country. If GDP of a country increases with the faster rate than the population then it shows that GDP per capita of that country is increasing and standard of living of peoples is also improving. GDP was first developed by Simon 
Kuznets [22] for a US congress report of 1934. In 1944 after the Brettonwood conference, GDP became the main tool for measuring the economy of a country. There is a debate among the economist and policy makers about the relationship between inflation and economic growth.

Some economist say that there is positive relationship between inflation and economic growth while other are in the favors of opposite relationship between inflation and economic growth [13]. Philip's curve also shows that there exist a positive relationship between inflation and economic growth. They showed this relationship through the channel of aggregate demand and aggregate supply. Keynesian views or policies get more importance during the period of economic crises of 1929. They believed that there is a positive relationship between inflation and economic growth. But in 1970 it was saw that the production level had been decreased with the increase in prices [14].

Saving is considered very important factor for the improvement of an economy of a country. It also plays a vital role in the individual's life. It has been seen that individual who has more savings, more satisfied to face the adverse shocks in the coming period. According to Modigliani, the rational people earn in the one part of their life such as in the working age and save money in this era for the older age. There are many other economists who believe that when the income of individual increase then the proportion of savings of that people will also increase such as Keynes in his theory concluded that when the income of the people increased then along with consumption percentage of saving also increased. At macro level it has been considered that the amount of savings is beneficial for the economic growth of a country. Pakistan is also facing the problem of lower savings during the last many years. During the time of 1973 to 2010, it has been seen that the savings rate was high in the year of 2003-04 which was 17.61 percent of total GDP while on the other hand it remained low in the period of 1979 which was 5.81 percent of GDP [25]. Along with economic growth policy makers considered savings as a major macroeconomic factor which has a strong relation with inflation. Sidrauski [31] in a general equilibrium framework found that money remained neutral in the time of steady state, so inflation has no impact on savings in the long run. But Den haan [11] found negative relationship between inflation and savings.

For the policymakers and the economists the association between economic growth and the savings is not only most important but also a hot issue. Many researcher and economists had analyzed this dilemma as cause and outcome relationship. There is strong empirical confirmation of the positive relationship between savings and growth [26]. A group of economists favors the capital fundamentalist point of view that savings cause growth. But others are in favors of Keynesian theory that growth is necessary for savings. Economic growth, savings and inflation are interconnected variables as discussed above and should therefore be endogenously determined simultaneously in the method. However most of the studies on these variables do not examine them in a simultaneous equation structure. It is essential for a official to know the dynamics among the economic growth, savings and inflation in the structure.

\subsection{Objectives of the Study}

1. To investigate the relationship among the Inflation, Economic growth and savings.

2. To determine the threshold level of inflation in Pakistan.

3. Policy suggestions.

\section{Literature Review}

Davidson and mackinnon [10], investigated the relationship between inflation and savings rate for the economy of America and Canada. By using chow test they concluded that high inflation leads to high savings and unanticipated inflation leads to involuntary savings. In 2001, Sahoo examined that higher economic growth is necessary for increasing the savings of a country. So repudiating the traditional view that savings had been the engine of the economic growth. On the other hand in [30], Sheggu found a bidirectional causality between savings and economic growth for Ethopian economy. Faria and Carneiro [16] conducted the study to check the impact of high inflation on economic growth in the long run and short run. By employing VAR model, they concluded that inflation had negative impact on economic growth in the short run while no relationship was found between inflation and economic growth in the long run. Malik and Chowdhury [23] found that there exist short run as well as long run relationship between inflation and economic growth for the economies of Bangladesh, India, Sri lanka and Pakistan. Hussain and Malik [18] investigated the inflation rate which is harmful for the economy of Pakistan and found that $9 \%$ rate of inflation is tolerate able for Pakistan economy. Study also found a negative relationship between inflation and economic growth. Chaturvedi [9] estimated the inter-relationship between economic growth, savings and inflation in south east and south Asian countries. Panel data were used from 1989 to 2003. Results were estimated by using two stage least square method. Study found that saving and economic growth had positive relation. Inflation was positively related to saving but negatively related to economic growth in the analysed countries.

\section{Material and Methods}

\subsection{Data}

Annual time series data were used from 1972 to 2010. The data were taken from World development indicator (WDI) and International financial statistics (IFS). Methdology is based on three the simultaneous equations system.

\subsection{Methodology}

This study is based on the simultaneous equations system. Three equations were used in the study to complete the model. Unlike single equation in simultaneous equation there is two way causation or simultaneous relationship between two or more variables.

If there is two way causation in the function then this shows that the given function cannot be handle as a single 
equation function, but this belongs to broad structure of equations which shows the relationship between all the related variables. If two variables are mutually dependant with each other that is $Y=f(X)$ but also $X=f(y)$ then we have no authorized to make use of single equation function to find the relationship between analyzed variables. In that situation researcher have to use multi equations system which include different equations in which both $\mathrm{X}$ and $\mathrm{Y}$ appear as the endogenous variables while they may be shown as a explanatory variables in the next equation of the system.. In that situation the parameter of simultaneous equation model cannot be estimated by applying ordinary least square (OLS) because it violates an important assumption of classical linear regress in model which is the explanatory variables are free from error term. So in that situation ordinary least square (OLS) cannot be used because by applying OLS on the multi system equation the obtaining results will be biased and inconsistent. In simultaneous equation model the first step is to check the identification of the model or equation whether it is under identified, exactly identified or over indentified. If the model is under-identified then it cannot be estimated by any method. Indirect least square (ILS) method is used when model is exactly identified and when model or equation is over identified then two stages least square (2SLS) technique is used to find out the results of the parameters. According to the order condition for identification, it was found that the above equations were over identified so Two stages least square (2SLS) method is used to check the relationship among the above variables.

Model 1. Simultaneous equation model

Equation No: 1

$$
\mathrm{Y}_{\mathrm{t}}=\alpha_{1} \mathrm{IF}_{\mathrm{t}}+\alpha_{2} \mathrm{~S}_{\mathrm{t}}+\alpha_{3} \mathrm{IR}_{\mathrm{t}}+\alpha_{4} \mathrm{DEPR}_{\mathrm{t}}+\alpha_{5} \mathrm{DS}_{\mathrm{t}}
$$

Equation No: 2

$$
\mathrm{IF}_{\mathrm{t}}=\beta_{1} \mathrm{Yt}+\beta_{2} \mathrm{St}+\beta_{3} \mathrm{UNt}+\beta_{4} \mathrm{LITt}+\beta_{5} \mathrm{IRt}
$$

\section{Equation No: 3}

$$
\begin{aligned}
& \mathrm{S}_{\mathrm{t}}=\gamma_{1} \mathrm{Y}_{\mathrm{t}}+\gamma_{1} \mathrm{IF}_{\mathrm{t}}+\gamma_{3} \mathrm{DR}_{\mathrm{t}}+\gamma_{4} \mathrm{FDI}_{\mathrm{t}} \\
& +\gamma_{5} \mathrm{DEPR}_{\mathrm{t}}+\gamma_{6} \mathrm{DS}_{\mathrm{t}}+\gamma_{7} \mathrm{INV}_{\mathrm{t}}
\end{aligned}
$$

\section{Variable description}

$\mathrm{Y}=\mathrm{GDP}$ Growth rate

IF = Inflation rate

$\mathrm{S}=$ Savings rate

DEPR $=$ Depreciation rate

$\mathrm{DS}=$ Total debt servings

$\mathrm{IR}=$ Interest rate

$\mathrm{UN}=$ Unemployment rate

LIT $=$ Log of indirect taxes
DR = Dependency ratio (\% of working age population)

FDI $=$ Foreign direct investment

INV $=$ Total investment

\section{Model 2. Threshold level}

Threshold level for inflation and economic growth examined the point of inflexion or non-linear relationship between the analyzed variables. There are the questions, that numerous recent empirical studies have examined, focusing specifically on whether the relationship between inflation and long-run growth is a nonlinear. Khan and Senhadji [20] estimated the threshold level of inflation for developing and also developed countries. Ahmed and Mortaza [2] also used the unchanged model for the case of Bangladesh. By using the same model, consider the subsequent equation for the estimation of the threshold level of inflation for the case of Pakistan.

$$
\begin{aligned}
& \log (\mathrm{GDP}) \mathrm{t}=\chi_{0}+\chi_{1} \mathrm{INFLR}_{\mathrm{t}} \\
& +\chi 2 \mathrm{D}\left(\mathrm{INFLR}_{\mathrm{t}}-\mathrm{K}\right)+\epsilon_{\mathrm{t}-------} 1
\end{aligned}
$$

In that above mentioned equation the Economic growth and inflation are computed as:

Growth $=$ LOG $\left(\mathrm{GDP}_{\mathrm{t}}\right)$

$\mathrm{INFR}_{\mathrm{t}}=$ inflation rate (\% annually)

The dummy variable is defined as follows:

$\mathrm{D}=1$ if INFLR $>\mathrm{K}$

$\mathrm{D}=0$ if $\mathrm{INFLR} \leq \mathrm{K}$

Where, $\mathrm{K}$ shows the threshold level of the inflation at which, structural break occurs; $\mathrm{Et}$ is random error term which represents measurement error in the explanatory variables.

Threshold level of inflation is determined at that point where the value of $\mathrm{R}^{2}$ is maximum. This also implies that most favorable value of the threshold level is that which minimizes the residual sum of squares (RSS). Threshold level of inflation for the economy of Pakistan is to be checked by using the method of Ordinary Least Square (OLS).

\section{Results and Discussion}

This section belongs to very important part of the study because in this chapter we achieve our goals. This chapter consists of two separately empirically estimation. The empirically analysis of the relationship among economic growth, savings and inflation has done by using the simultaneous equations model by applying 2SLS method on these equations. The second objective of the study which is threshold level of inflation for the economy of Pakistan has been estimated through OLS. The empirical results and their brief discussion is given below.

Table 1. Structural Form Parameter Estimates of inflation rate

\begin{tabular}{|c|c|c|c|}
\hline Variables & Coefficients & Std. error & T-statistics \\
\hline GDP & -0.45 & 0.23 & -1.96 \\
\hline Savings & 0.24 & 0.25 & 0.95 \\
\hline Unemployment rate & -0.92 & 0.32 & -2.90 \\
\hline Indirect taxes & 1.29 & 0.31 & 0.35 \\
\hline Real interest rate & -0.89 & 0.09 & 0.0065 \\
\hline
\end{tabular}

$\mathrm{R}^{2}=0.78$ Durban Watson $=1.76$

In Table 1 the value of $\mathrm{R}^{2}$ which is 0.78 shows that $78 \%$ variation in the dependent variable is explained by related independent variables. The coefficient of GDP growth shows that GDP growth has significant impact on inflation.
The negative sign of coefficient shows that there is a negative relationship between inflation and economic growth. The value of coefficient indicates that $1 \%$ increase in GDP growth brings. 45\% reduction in the rate 
of inflation. The reason behind this negative relationship is that when the production of goods increased then the supply of these goods increased which reduced the prices of goods. Many other researchers also found that there is a negative relationship between inflation and economic growth Barro [6], Dewan and hussain [12] Khan and senhadji [20]. By regressing the savings rate on the inflation rate it is found that the co-efficient value of savings rate shows that savings rate has an insignificant impact on the prices. The positive sign shows the positive relationship between the analyzed variables. The coefficient value of unemployment shows that there is statistically significant impact of unemployment on the rate of inflation. The negative sign of the coefficient express the existing of negative relationship between unemployment and the prices. The reasons behind this negative relationship between the analyzed variables is that for when unemployment increased its means that people have less money so the demand of goods and services decreased and as a result inflation also decreased. Berger [7] had also found that increase in unemployment will lead to reduction in the level of output which ultimately causes to decrease in the inflation.
In the Table 1 the value of indirect tax indicates the statistical highly significant impact of indirect taxes on the inflation rate. The positive sign of the coefficient shows the positive relationship between indirect taxes and price level. The justification of this positive relationship between indirect taxes and inflation is that when indirect tax is imposed then the cost of production of goods increased and as a result prices of goods also increased and this increase in the prices becomes the cause of increase in the price level. Patoli et, al. [28] found the same results that there is positive and significant relationship between inflation and indirect taxes. The coefficient of real interest rate shows the highly significant impact of real interest rate on the price level. The negative sign of the coefficient shows that there exist negative relationship between inflation level and interest rate. The justification of negative relationship is that in general it has been seemed that when interest rate is low then people can borrow more money. As a result consumer or people have more money for spending and caused the economy to grow and also price level to increase. Ball [5] also found a negative relationship between the interest rate and inflation level.

Table 2. Structural Form Parameter Estimates of GDP growth rate

\begin{tabular}{|c|c|c|c|c|}
\hline Variables & Coefficient & Std. error & t-statistics & -3.65 \\
\hline Inflation rate & -0.47 & 0.13 & Probability & 0.0009 \\
\hline Savings rate & 0.14 & 0.08 & 0.1107 \\
\hline Real interest rate & -0.43 & 0.13 & -3.21 \\
\hline Depreciation rate & 0.64 & 0.05 & 11.63 \\
\hline Total debt servicing & 0.02 & 0.22 & 0.0029 \\
\hline $\mathrm{R}^{2}=0.64$ Durban Watson $=1.82$ & 0.0000 & 0.12 \\
\hline
\end{tabular}

$\mathrm{R}^{2}=0.64$ Durban Watson $=1.82$

The value of $\mathrm{R}^{2}$ in the Table 2 shows that $64 \%$ variation in dependent variables explained by independent variables. The negative sign of inflation explain the existing of negative relationship between inflation rate and GDP growth. The coefficient value of inflation which is 0.47 indicates that 1 percent increase in the prices brings 0.47 percent reduction in the growth rate. The value of probability which was 0.0009 indicated that inflation highly significant to bring change in the economic growth because the change in prices create uncertainty among the investor about their future profit. This may confused the investor for taking investment decision, which ultimately reduce the level of investment in the future and hence reduce the economic growth. The results of this study relates with the results of (Ayyoub et, al. [3]; Khan and Senhadji [20]; Ghosh and Philips, [17]; Ahmad and Murtaza, [2]. The positive sign of savings show that there is positive relationship between savings and economic growth of Pakistan. The value of probability (.11) shows that there is insignificant relationship between savings and economic growth. The coefficient value of interest rate has negative sign which indicates that higher interest rate is harmful for the economic growth of Pakistan. The reason behind this negative relationship between real interest rate and economic growth is that at the time of increase in real interest rate people prefer to deposit their money in the banks rather investment and investment will be low then ultimately economic growth will be low. On the other hand it has been estimated that there is a positive relationship between depreciation rate and GDP growth. Depreciation of currency enhances the exports of that country because now exports become cheaper for foreigner due to the depreciation and hence increased the economic growth of that country. When the demand of exports increased this thing motivate the investor to increase the production of those goods and as a result economic growth increased. The probability value of debt servicing shows that debt servicing has insignificant impact on economic growth of Pakistan.

\begin{tabular}{|c|c|c|c|c|}
\hline Variables & Coefficient & Std. error & t-statistics & Probability \\
\hline GDP & 6.01 & 1.72 & 3.49 & 0.0015 \\
\hline Inflation rate & -0.07 & 0.11 & -0.63 & 0.5305 \\
\hline Dependency ratio & 0.58 & 0.14 & 3.94 & 0.0004 \\
\hline Foreign direct investment & 4.45 & 0.68 & 6.53 & 0.0000 \\
\hline Depreciation rate & -5.50 & 1.48 & -3.69 & 0.0008 \\
\hline
\end{tabular}

In Table 3 the value of $\mathrm{R}^{2}(0.55)$ shows that $55 \%$ variation in Savings of Pakistan is due to the Inflation, economic growth, dependency ratio, foreign direct investment and depreciation rate.

The calculated value of the coefficient of GDP growth rate shows the highly significant impact of economic growth on the savings rate. The positive sign of GDP Growth indicates positive relationship between output level and savings. For the justification of the positive relationship between output and savings it can be said that when economic growth will be more its means that people's incomes will also be greater and ultimately 
savings will be more. The results of this study relates to the Keynesian theory which say that savings of any country depends on the level of output. Modigliani [26] had also showed the similar results. He argued that a very simple version of life cycle model can also predict that higher growth cause more savings. Jappelli and Pagano [19] also showed the same results and provide some evidence in the favor of positive relationship between savings and economic growth and causality runs from economic growth to the savings. The negative sign of inflation shows the opposite relationship between savings and inflation while the value of probability (0.53) shows the insignificancy of inflation for Savings. when prices will be high then people have to pay more money to buy goods and services and hence their savings will decreased. The coefficient value of dependency ratio shows that when the volume of working age people increase then the savings also increased. These results confirm the life cycle hypothesis of Modigliani who argued that the household who have less children and older people have to bear less expenditure in relation to the income level of the household to look after them and hence they would save more proportion of their income. The positive sign of Foreign direct investment indicates the positive relationship between FDI and saving rate. The reason behind this positive relationship is that foreign capital inflow increased the supply of funds for investment thus enhancing the capital accumulation in host country. When investment will be more then economic growth will increase and consequently the saving rate stimulate. The results of Foreign direct investment are similar with the results of (Egbo and Onwumere [15]; Bataineh [4]; Chang [8]. The coefficient value of depreciation rate shows that there is opposite relationship exists between rate of depreciation and savings. The reason for this negative relationship was that when the currency of a country depreciates then the burden of foreign debt increased which reduced the level of savings.

\subsection{Threshold Model Estimation}

The estimations of the model of threshold is done by using the method of ordinary least square (OLS) is reported in the below tables which gives the correct value of the threshold level of inflation. The procedure has been repeated many times. The estimated R-square and residual sum of square were taken into account for the determination of the threshold level of inflation taking into account the assumed values of covering the $\mathrm{K}$ from 1 to 13. However, taking into consideration the value of residual sum of square and the value of R-square the anticipated results have been presented in the below given tables for the $\mathrm{K}$ values of ranging from $6 \%$ to $11 \%$.

Table 4. Results of OLS for threshold level of inflation

\begin{tabular}{|c|c|c|c|c|c|c|}
\hline $\mathrm{K}$ & Variables & Coefficients & Std. error & T-statistics & $\mathrm{R}^{2}$ & RSS \\
\hline 6 percent & $\begin{array}{c}\text { Constant } \\
\text { INF } \\
\text { D(Dummy) }\end{array}$ & $\begin{array}{c}28.81 \\
-0.03 \\
0.06 \\
\end{array}$ & $\begin{array}{c}0.2 \\
0.02 \\
0.25 \\
\end{array}$ & $\begin{array}{c}143.62 \\
-1.5 \\
0.24\end{array}$ & 0.07 & 10.54 \\
\hline 7 percent & $\begin{array}{c}\text { Constant } \\
\text { INF } \\
\text { D(Dummy) }\end{array}$ & $\begin{array}{c}20.78 \\
0.05 \\
0.35 \\
\end{array}$ & $\begin{array}{l}0.18 \\
0.02 \\
0.24 \\
\end{array}$ & $\begin{array}{c}161.93 \\
-2.26 \\
1.50\end{array}$ & 0.12 & 9.93 \\
\hline 8 percent & $\begin{array}{c}\text { Constant } \\
\text { INF } \\
\text { D(Dummy) }\end{array}$ & $\begin{array}{c}28.85 \\
-0.04 \\
0.19\end{array}$ & $\begin{array}{l}0.18 \\
0.02 \\
0.25\end{array}$ & $\begin{array}{c}159.40 \\
-1.72 \\
0.77\end{array}$ & 0.08 & 10.39 \\
\hline 9 percent & $\begin{array}{c}\text { Constant } \\
\text { INF } \\
\text { D(Dummy) }\end{array}$ & $\begin{array}{c}28.90 \\
-0.05 \\
0.39\end{array}$ & $\begin{array}{l}0.18 \\
0.02 \\
0.25\end{array}$ & $\begin{array}{c}160.58 \\
-2.29 \\
1.55\end{array}$ & 0.13 & 9.88 \\
\hline 10 percent & $\begin{array}{c}\text { Constant } \\
\text { INF } \\
\text { D(Dummy) }\end{array}$ & $\begin{array}{c}28.89 \\
-0.04 \\
0.22\end{array}$ & $\begin{array}{l}0.19 \\
0.02 \\
0.28\end{array}$ & $\begin{array}{c}147.48 \\
-1.67 \\
0.78\end{array}$ & 0.08 & 10.39 \\
\hline 11 percent & $\begin{array}{c}\text { Constant } \\
\text { INF } \\
\text { D(Dummy) }\end{array}$ & $\begin{array}{c}28.96 \\
-0.05 \\
0.40 \\
\end{array}$ & $\begin{array}{l}0.20 \\
0.02 \\
0.30 \\
\end{array}$ & $\begin{array}{c}144.48 \\
-2.11 \\
1.34\end{array}$ & 0.11 & 10.04 \\
\hline
\end{tabular}

The above Table 4 showed that 9\% rate of inflation is tolerate able for the economic growth of Pakistan. Because at this point the value of $\mathrm{R}$-square is maximum whereas the value of residual sum of square is minimum which indicated that the model is best fit at 9\% level? The value of probability also showed that the two variables significantly affected each other in the long run. The sign of the coefficient remained negative at all the $\mathrm{K}$ levels such as from $6 \%$ to $11 \%$. Many economist are in the favor of that view that inflation rate in the double digit is harmful for economic growth. Such as Hussain and Malik [18] also confirmed the hypothesis that when the inflation rate crossed the single digit then it is detrimental for economic growth.

\section{Conclusion}

The results of 2SLS model shows that there exist bi directional causality between inflation and economic growth and the results also revealed that they negatively affect each other in the long run. It has been also found that indirect taxes have positive relation with prices whereas unemployment and real interest rate are negatively correlated with inflation. It has been also observed that real interest rate has negative while depreciation rate has positive impact for the economic growth of Pakistan. Unidirectional causality found from GDP growth to savings. The results of the study show that GDP growth, Dependency ratio and Foreign direct investment positively affect savings whereas depreciation rate is harmful for the savings for the economy of Pakistan. No significant relationship was found between inflation and savings. Threshold level of inflation for the economic growth was also checked through OLS method. The rate of inflation was taken from $6 \%$ to $11 \%$. The result revealed that 9 percent rate of inflation is beneficial for the economic growth of Pakistan.

\section{Suggestions and Policy Implications}

1. It is enviable to keep the rate of inflation in the single digit and central bank adopted those policies which 
will be helpful for keeping the inflation rate lower than 10 percent.

2. some suitable steps have to be taken for decreasing the real interest rate and also for increasing the economic growth and controlling the prices.

3. indirect taxes should be reduced for controlling the inflation rate. In this scenario, government can play a vital role to reduces the rate of indirect taxes.

4. Government has to gives incentives the foreign investors for boosting the level of investment in the country because investment is necessary for enhancing the savings of a country.

5. GDP growth is the main tool for increasing the savings of a country. So necessary steps have to be taken by the government for boosting the output for increasing the savings of public as well as private sectors.

\section{References}

[1] Ahortor and Adenutsi (2009) Inflation, Capital accumulation and Economic growth in import-dependent developing economies. Department of Economics, University of Cape Coast and Central University College, Ghana.

[2] Ahmad, Shamim and M. G. Murtatza (2005). Inflation and economic growth on Bangladesh: 1981-2005, working paper series: WP 0604, policy analysis unit (PAU).

[3] Al-Abdulrazag, B., Bataineh, T.M. (2007), "Causal Relationship between Foreign Direct Investment and Savings in Jordan: An Error Correction Model”, International Management Review, 3 (4), 2007, pp. 12-18.

[4] Ayyoub et al (2011) Does inflation affects economic growth? The case of Pakistan. Pakistan Journal of Social Sciences, 31 (1), 5164.

[5] Ball, Laurence, (1990) "Efficient Rules for Monetary Policy," International Finance 2 (1) (1990): 63-83.

[6] Barro, Robert J. (1995) inflation and economic growth, working paper 5326, national bureau of economic research.

[7] Berger A, Bouwman C (2010) Bank liquidity creation, monetary policy and financial crises. Working Paper, Wharton Financial Institutions Center.

[8] Chung, C., Chang, L., Zhang, Y., (1995) "The Role of Foreign Direct Investment in China's Post-1978 Development”, World Development, 23 (4), 1995, pp, 691-707.

[9] Chaturvedi, V., Kumar. and Dholakia, R. (2009) Inter-relationship between Economic Growth, Savings and Inflation in Asia. Indian Institute of Management Ahmadabad Working Paper No. 01.

[10] Davidson. And Mackinnon, J. (1982) Inflation and Savings Rate. Queen's Economics Department Working Paper No. 493.

[11] Den Haan, W.J., 1990, The Optimal In ation Path in a SidrauskiType Model with Un-certainty, Journal of Monetary Economics, vol. 25, 389-409.
[12] Dewan, E and S. Hussein. (2001). "Determinants of Economic Growth”, Working Paper, Reserve Bank of Fiji.

[13] Dholakia, R. H. (1990). Extended Phillips curve for the Indian economy. Indian economic journal, vol. 38, no. 1, pp. 69-70.

[14] Earbaykal, E. and Okuyan, H. (2008) Does Inflation depress Economic Growth? Evidence from Turkey. International Research Journal of Finance and Economics.

[15] Egbo, O and Onwumere, J (2011) Analysing the impact of foreign direct investment on Nigeria's economic growth: A co integration approach. International journal of research in management, vol No: 3 (2011), 78-97.

[16] Faria, J. and Carneiro, F. (2001) Does High Inflation Affect Growth in the Long and Short Run? Journal of Applied Economics, 4 (1), 89-105.

[17] Ghosh, Atish and Steven Phillips (1998). Inflation, disinflation and growth, IMF working paper, wp/98/68.

[18] Hussain, S. and Malik, S. (2011) Inflation and Economic Growth: Evidence from Pakistan. International Journal of Economics and Finance, 3 (5), 32-54.

[19] Jappelli, T. and Pagano, M. (1994). Saving, growth, and liquidity constraints. The Quarterly Journal of Economics, Vol. 109, No. 1, pp. 83-109.

[20] Khan, Mohsin S. and Abdelhak S. sinhadji (2001). Threshold effects in the relationship between inflation and economic growth. IMF staff paper, volume. 48. No. 1.

[21] Khalid, A. M. (2005). Economic growth, inflation and monetary policy in Pakistan. Preliminary empirical estimates. The Pakistan development review, 44 (4), 961-974

[22] Kuznets, S (1955) economic growth and income inequality. An American economic review Vol. No: 45, 1-28.

[23] Malik, Girijasankar and Anis Chowdhury (2001). Inflation and economic growth: evidence from four south Asian countries. Asiapecific development journal, vol. 8, no. 1. pp. 123-135.

[24] Maddison, A. (1992), A long run perspective on saving. Scandinavian Journal of Economics, Volume 94, pp. 181-196.

[25] Ministry of Finance (2011) Economic Survey 2011. Islamabad: Government of Pakistan.

[26] Modigliani, F. (1970). The life cycle hypothesis of savings and inter country difference in the savings ratio. Eltis, W.A., M.F. scott, J.N. Wolfe, (eds), induction to trade and growth: essay in honor of sir roy Harrod. Clarendon press, London.

[27] Modigliani, F. (1990), Recent development in saving rates: A life cycle perspective. Frisch Lecture, Sixth World Congress of the Econometric Society, Barcelona, Spain.

[28] Mubarik, Y. A. (2005). Inflation and growth: an estimate of the threshold level of inflation in Pakistan, state bank of Pakistan, research. Bulletin, vol. 1-2, pp. 35- 44.

[29] Rosegrant and Evenson. (1992). Agriculture investment and productivity in developing countries, American journal of economics. Vol. 74, no. 3, pp 757-761.

[30] Sheggu, D. (2004). Causal relationship between growth and gross domestic savings: Case of Ethopian economic association. Second international conference on the Ethopian economy, 3 (5).

[31] Sidrauski, M. (1967). Rational choice and patterns of growth in a monetary economy, American economic review, 57.

[32] The World Bank. 2007. Agriculture for development. World development report 2007. 